\title{
Food spectrum and dietary preferences of the Indian anchovy Stolephorus indicus (van Hasselt, 1823) from Thiruvananthapuram coast, Kerala
}

\author{
V. RAJANI GOPAL ${ }^{1}$, V. RAMASUBRAMANIAN ${ }^{1}$, B. SANTHOSH ${ }^{2}$ AND KURIAN MATHEW ABRAHAM ${ }^{3}$ \\ ${ }^{1}$ Department of Zoology, Bharathiar University, Coimbatore - 641 046, Tamil Nadu, India \\ ${ }^{2}$ Vizhinjam Research Centre of ICAR-Central Marine Fisheries Research Institute, Vizhinjam, Thiruvananthapuram - 695522 \\ Kerala, India \\ ${ }^{3}$ Department of Aquatic Biology and Fisheries, University of Kerala, Kariavattom, Thiruvananthapuram - 695581 \\ Kerala, India \\ e-mail: rajani.anil@yahoo.com
}

\begin{abstract}
The food preferences of the Indian anchovy Stolephorus indicus (van Hasselt, 1823) along the Thiruvananthapuram coast of Kerala was studied for a period of one year from June 2013 to May 2014, dividing the entire period into three seasons as pre-monsoon, monsoon and post-monsoon. A total of 141 samples were collected and the gut contents were analysed. The principal food item was the crustaceans which included copepods, lucifers, mysids, Acetes and amphipods. The other preferred prey items were molluscs (bivalves and gastropods), small fishes, tintinnids and dinoflagellates. The gastrosomatic and stomach fullness indices revealed almost uniform feeding preferences with copepods being the preferred food item throughout the three seasons. Analysis of variance showed significant $(\mathrm{p}<0.05)$ dominance of copepods and mysids in monthly consumption. No significant ( $>0.05$ ) seasonal variation was observed in the gut contents of $S$. indicus. Analyses of the different prey indices [prey diversity index (H), niche width indices (B) and prey evenness indices (e)] of $S$. indicus for the three seasons indicated an almost uniform distribution of prey species throughout the study period which directly indicate the abundance of the prey items and indirectly indicate a stable potential fishery and ecosystem.
\end{abstract}

Keywords: Food preferences, Gut content analysis, Indian anchovy, Prey indices, Stolephorus indicus, Stomach fullness indices

\section{Introduction}

The anchovies, belonging to the family Engraulidae, are small silvery pelagic fishes widely distributed along the tropical and subtropical regions of the Indo-Pacific. These are one of the important groups of food fishes which contribute significantly to the total marine fish production of India. India occupies $12^{\text {th }}$ position in the catch of anchovy (FAO, 2006). Anchovies contributed $45343 \mathrm{t}$ which is around $9.2 \%$ of the total marine fish landings of India (CMFRI, 2015). The Indian anchovy Stolephorus indicus (van Hasselt, 1823) forms an important fishery along the Kerala coast contributing $2.6 \%$ in the total anchovy landings of the state (CMFRI, 2016).

The present study attempted to analyse the food spectrum and dietary preferences of $S$. indicus from Thiruvananthapuram coast of Kerala. Analysis of the food preferences of an organism helps to give an insight into its life history, habitat preferences and energy requirements. Study of the food and feeding habits of fishes is essential to understand the life history of the fish including its growth, breeding and migration (Bal and Rao, 1984). Information on the feeding habits of a marine fish and its predator-prey relationship is useful for assessing its role in the ecosystem (Bachok et al., 2004). Awareness about the influence of maturity stages, age and seasons on food and feeding preferences are of great value in assessing the trophic inter-relations and therefore study of food and feeding preferences forms an inevitable part of fish biology.

The feeding biology of fishes has ever been a topic of great interest to researchers across the world. Some of the outstanding works in this field are those of Hynes (1950), Maclean (1971), Hyslop (1980), Russel (1983), Gunn and Milward (1985), Shaheen et al. (2001) and Hajisamae et al. (2003; 2006). A handful of information is already available from different countries on the food and feeding ecology of anchovies (Cunningham, 1890; Tudela and Palomera, 1995; Plounevez and Champalbert, 2000; Catalan et al., 2010; Schaber et al., 2010; Raab et al., 2011). Notable Indian works include those of Venkataraman (1960), Rabindranath (1966), Babu Rao (1967), Srinivasa Rao (1964), Luther (1979), Thangavelu et al. (1987) and Gopakumar et al. (1995). Howerver, only very little information is available on the food preferences of the Indian anchovy, S. indicus. Hence during the present 
study, an attempt was made to investigate details of the dietary contents and feeding preferences of $S$. indicus.

\section{Materials and methods}

Samples of $S$. indicus for the study were collected from the landings of gillnets, shore seines and ring seines from Vizhinjam and nearby fish landing centers of Thiruvananthapuram coast, Kerala for a period of one year from June 2013 to May 2014. Immediately after collection, the specimens were transported in ice boxes to the laboratory for further analysis.

Fishes in all stages of maturity were included in the study. A total of 141 specimens were examined comprising of 45 males and 96 females. Before gut content analysis, the total length $(\mathrm{mm})$ and whole body weight $(\mathrm{g})$ of samples were recorded using a Vernier calipers and a digital balance (Shimadzu), respectively. The fishes were dissected under a stereozoom dissecting microscope (Leica S8) to examine the sex, fullness of stomach and its dietary components.

The degree of fullness of stomach and the quantity of food contained in it were noted so as to ascertain the extent of feeding (feeding intensity). The degree of distension of stomachs were designated as gorged (50 points), full (40 points), $3 / 4$ full (30 points), $1 / 2$ full (20 points), $1 / 4$ full (10 points) and empty ( 0 points) following the method by Hynes (1950). A stomach was considered 'gorged' when it was packed with food and stretched fully with thin, transparent walls, 'full' when filled with food and the walls thick and intact and ' $3 / 4$ full' when the stomach was partly collapsed with thick walls. Depending on the amount of food present and appearance of the stomach wall, the stomach was further designated as ' $1 / 2$ full', ' $1 / 4$ full' and 'empty'. Weight of the stomach was measured to nearest milligram in a digital balance (Shimadzu) for the estimation of gastrosomatic index (GSI) which was calculated as per Desai (1970) as:

GSI = Weight of the stomach $\mathrm{x} 100$ / Total weight of the fish

The stomach was then cut open and the contents were examined under a binocular microscope. Stomach contents were identified up to group level and whenever possible identification was attempted upto generic level depending on the state of digestion or degeneration of the contents. Based on the season, the entire study period was divided into pre-monsoon (February to May), monsoon (June to September) and post-monsoon (October to January).

The percentage composition of the diet was determined following the points method (Hyslop, 1980). The percentage of occurrence of each food item was calculated month-wise and a comparison of the mean percentage of occurrence of food items between male and female fishes were also made.
Prey diversity was calculated using the ShannonWiener Information Measure $(\mathrm{H})$ as:

$\mathrm{H}=-\sum\left[p_{i}\right] l_{n}\left[p_{i}\right]$

where $p_{i}=$ the proportion of each different food item contributing to the whole diet.

The data from the dietary analyses were used to calculate diet breadth, using the niche width index (B) described by Levins (1968), using the formula:

$$
\mathrm{B}=\frac{1}{\Sigma\left[p_{i}\right]^{2}}
$$

This index was used to compare 'specialist' tendencies between species/size classes, with low values of the index indicating specialists and high values generalists (Gibson and Ezzi, 1987).

Prey evenness (Gibson and Ezzi, 1987) that measures how evenly the prey species are distributed in the diet was calculated as follows:

$$
\begin{aligned}
& \mathrm{e}=\frac{H}{H_{\max }} \\
& \text { where } \mathrm{H}_{\max }=l_{n} \mathrm{~S} \text { and } l_{n} \mathrm{~S} \text { is the natural logarithm of }
\end{aligned}
$$
the number of food types.

\section{Results and discussion}

Results of analysis of gut contents during the present study indicated that $S$. indicus is a zooplanktivorous fish. The diet consisted predominantly of three groups viz., crustaceans, molluscs and small fishes. Tintinnids, dinoflagellates and digested/unidentified matter were the other minor food items observed (Fig. 1). The single most dominant food item was the crustaceans both by number and occurrence. The preferred crustaceans included copepods (46.73\%), lucifers (23.44\%), amphipods (4.24\%), mysids (1.81\%) and Acetes (1.30\%). Molluscan food items included gastropods $(5.29 \%)$ and bivalves $(5.23 \%)$. Fish remains contributed $8.96 \%$ of the diet while digested matter, tintinnids and dinoflagellates formed $1.63,0.55$ and $0.59 \%$ respectively.

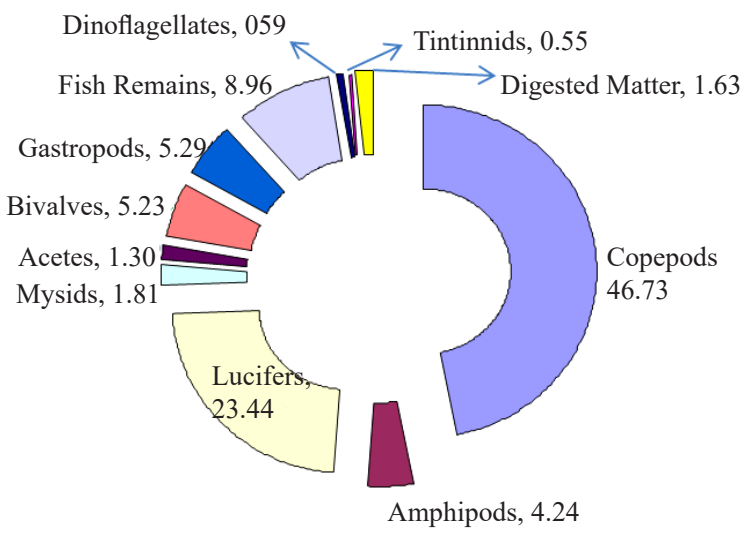

Fig. 1. Annual food spectrum of $S$. indicus 
Observations on the diet composition indicated that $S$. indicus had preference for copepods and preferred to feed on them solely when they are available in plenty. Earlier experimental studies conducted by Vijayaraghavan (1953; 1957) on a related species, S. insularis showed that their post-larvae are purely carnivorous and were found to prey upon planktonic organisms including copepods. Venkataraman (1960) in his studies on the food and feeding relationships of the inshore fishes off Calicut along Malabar coast observed that in $S$. tri and Encrasicholina heteroloba, (copepods formed a major food constituent in all the months examined. Observations of Rabindranath (1966) indicated that over $60 \%$ of the food of $S$. commersoni consisted of common zooplanktonic organisms such as copepods, ostracods, amphipods, cladocerans, mysids and occasionally fish eggs and larvae were also observed. Luther (1972) reported that the food of $E$. devisi and $S$. waite $i$ were mainly copepods, small crustaceans and small bivalves. Direct relationship between zooplankton densities and Anchoviella spp. distribution has been reported along the south-west coast of India (IMR/NORAD/FAO, 1974). Results of the present study also confirmed that the Indian anchovy $S$. indicus is a zooplanktivorous fish with a clear preference for planktonic crustaceans.

Syda Rao (1988) observed that E. devisi fed on a wide variety of zooplanktonic organisms dominated by copepods. Phytoplankton like Coscinodiscus spp. were also occasionally observed in the diet. Thangavelu et al. (1987) reported that food of $S$. devisi along the Madras coast was mainly constituted by copepods, mysids, megalopa larvae of crabs, fish eggs, cypris larvae of barnacles and tintinnids. Sporadic occurrence of phytoplankton was also observed by them. The stomach contents of E. punctifer along Vizhinjam, south-west coast of India comprised almost entirely of copepods (Gopakumar et al., 1995).
Results of the present study on the diet composition of $S$. indicus is in agreement with the earlier observations on related species. Among crustaceans, copepods made up a greater part of the food (46.73\%) throughout the study period. Lucifers were seen in most of the months during the entire period of study with a maximum occurrence in January 2014. Small fishes and fish larvae were found in good quantities in all the months. Bivalves and gastropods though absent in certain months, were more represented in the diet than mysids, Acetes and amphipods. Tintinnids and dinoflagellates seemed to be ingested in lesser amounts in most of the months. The percentage of digested/unidentified matter varied in different months. The monthly percentage of occurrence of different dietary groups is presented in Table 1.

Copepods and mysids showed significant $(\mathrm{p}<0.05)$ dominance in monthly consumption than all other food items. Copepods formed a major food item and contributed nearly $50 \%$ of its gut content in all the months (Table 1). The percentage occurrence of copepods was least in October which may be due to the lesser availability of the same during that month. Similarly, mysids were preferred during June which could be attributed to its higher occurrence during that period. In case of other food items, no significant difference was observed between months, which indicating absence of temporal variation. Again the results suggested that the food items for the species were abundant throughout year without much variation in their availability.

A comparison of the seasonal occurrence of different food items (Table 2) indicated that in all the three seasons (pre-monsoon, monsoon and post-monsoon), copepods were the most preferred food item, while least preference was for tintinnids and dinoflagellates. No significant $(p>0.05)$ variation was observed between seasons for all the food items present in the gut contents of $S$. indicus indicating that there was no seasonal preference for food

Table 1. Percentage of occurrence (Mean \pm SD) of different food items in $S$. indicus during the study period

\begin{tabular}{|c|c|c|c|c|c|c|c|c|c|c|c|}
\hline $\begin{array}{l}\text { Month }{ }^{\#} \\
(2013-14)\end{array}$ & Copepods & Amphipods & s Lucifers & Mysids & Acetes & Bivalves & Gastropods & Fish remains & Tintinnids & Dinoflagellates & $\begin{array}{l}\text { Digested } \\
\text { matter }\end{array}$ \\
\hline June, 2013 & $53.64 \pm 9.24 *$ & $3.64 \pm 6.74$ & $19.09 \pm 10.20$ & $6.36 \pm 9.24 *$ & $0.45 \pm 1.51$ & $4.09 \pm 5.39$ & $1.36 \pm 3.23$ & $6.82 \pm 7.83$ & $1.00 \pm 2.80$ & $1.00 \pm 2.80$ & $1.33 \pm 5.16$ \\
\hline July & $41.01 \pm 12.15$ & $4.12 \pm 5.71$ & $26.19 \pm 7.11$ & $0.60 \pm 1.55$ & $1.90 \pm 2.76$ & $7.49 \pm 7.12$ & $7.92 \pm 7.57$ & $8.76 \pm 8.50$ & $0.17 \pm 0.65$ & $0.33 \pm 0.88$ & $1.38 \pm 2.42$ \\
\hline August & $44.29 \pm 11.65$ & $3.45 \pm 5.17$ & $26.19 \pm 10.05$ & $0.48 \pm 1.21$ & $1.07 \pm 2.23$ & $6.55 \pm 6.04$ & $7.26 \pm 7.44$ & $8.57 \pm 6.06$ & $0.56 \pm 1.50$ & $0.56 \pm 1.50$ & $0.89 \pm 1.98$ \\
\hline September & $48.21 \pm 11.27$ & $4.10 \pm 6.26$ & $25.38 \pm 7.01$ & $0.51 \pm 1.85$ & $1.67 \pm 3.33$ & $3.72 \pm 4.62$ & $2.95 \pm 4.09$ & $10.77 \pm 7.98$ & $0.44 \pm 1.72$ & $0.22 \pm 0.86$ & $1.67 \pm 3.62$ \\
\hline October & $37.00 \pm 12.19$ & $5.44 \pm 5.14$ & $26.22 \pm 14.18$ & $2.44 \pm 3.14$ & $1.33 \pm 2.01$ & $5.56 \pm 6.60$ & $5.00 \pm 6.01$ & $12.44 \pm 13.35$ & $0.44 \pm 1.72$ & $0.22 \pm 0.86$ & $3.89 \pm 6.32$ \\
\hline November & $51.17 \pm 12.68$ & $5.10 \pm 5.61$ & $16.91 \pm 11.92$ & $2.00 \pm 5.28$ & $0.83 \pm 1.81$ & $4.12 \pm 5.52$ & $7.54 \pm 8.00$ & $10.72 \pm 10.34$ & $0.00 \pm 0.00$ & $0.00 \pm 0.00$ & $1.60 \pm 3.56$ \\
\hline December & $47.98 \pm 12.91$ & $1.55 \pm 3.23$ & $22.98 \pm 6.41$ & $1.79 \pm 3.23$ & $0.24 \pm 0.89$ & $6.90 \pm 6.69$ & $6.90 \pm 6.37$ & $8.45 \pm 10.14$ & $0.67 \pm 1.87$ & $0.67 \pm 1.87$ & $1.67 \pm 3.62$ \\
\hline January, 2014 & $51.11 \pm 10.18$ & $0.00 \pm 0.00$ & $28.89 \pm 11.71$ & $0.00 \pm 0.00$ & $0.00 \pm 0.00$ & $2.22 \pm 3.85$ & $2.22 \pm 3.85$ & $14.44 \pm 13.47$ & $0.00 \pm 0.00$ & $0.00 \pm 0.00$ & $1.11 \pm 1.92$ \\
\hline April & $49.05 \pm 9.19$ & $6.43 \pm 8.91$ & $23.10 \pm 9.80$ & $1.55 \pm 3.23$ & $2.26 \pm 3.18$ & $7.02 \pm 6.38$ & $2.62 \pm 3.18$ & $5.60 \pm 4.22$ & $0.89 \pm 1.98$ & $1.33 \pm 2.76$ & $0.00 \pm 0.00$ \\
\hline May & $48.82 \pm 15.36$ & $4.80 \pm 7.40$ & $23.24 \pm 12.11$ & $1.76 \pm 3.51$ & $1.96 \pm 3.29$ & $2.55 \pm 3.82$ & $5.49 \pm 7.19$ & $7.06 \pm 7.51$ & $0.83 \pm 2.00$ & $1.02 \pm 2.37$ & $2.22 \pm 5.24$ \\
\hline
\end{tabular}

*Significant at $\mathrm{p}<0.05$; \# No fish landing during February and March 2014 


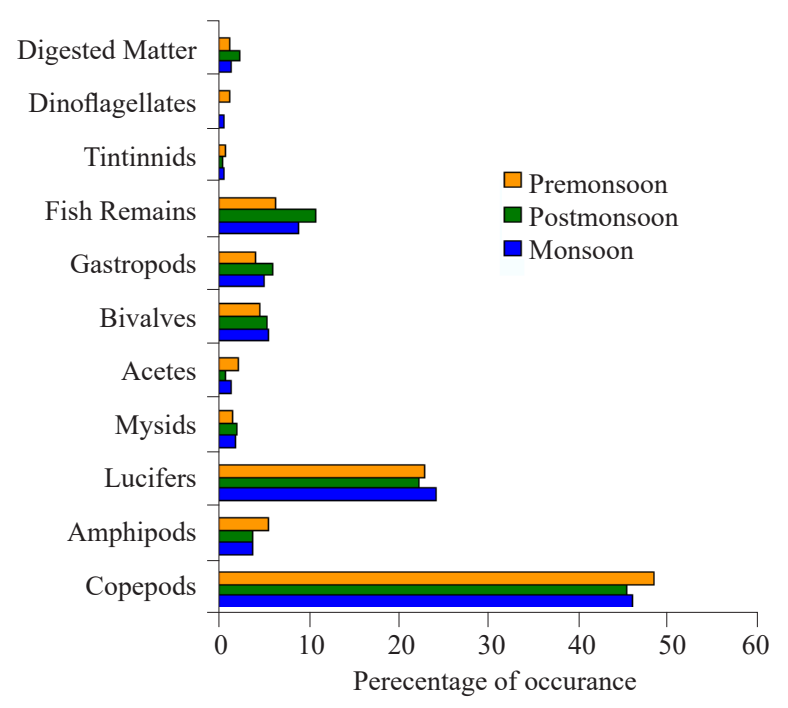

Fig. 2. Seasonal difference in percentage occurrence of food items in $S$. indicus

Table 2. Season-wise percentage occurrence (Mean \pm SD) of different food items in $S$. indicus

\begin{tabular}{llll}
\hline Food Items & Monsoon & Post-monsoon & Pre-monsoon \\
\hline Copepods & $46.36 \pm 11.84$ & $45.69 \pm 13.55$ & $48.92 \pm 12.75$ \\
Amphipods & $3.83 \pm 5.77$ & $3.83 \pm 4.95$ & $5.54 \pm 8.02$ \\
Lucifers & $24.49 \pm 8.87$ & $22.45 \pm 11.81$ & $23.17 \pm 10.95$ \\
Mysids & $1.76 \pm 4.93$ & $1.95 \pm 3.84$ & $1.67 \pm 3.33$ \\
Acetes & $1.31 \pm 2.56$ & $0.76 \pm 1.64$ & $2.10 \pm 3.19$ \\
Bivalves & $5.57 \pm 5.96$ & $5.29 \pm 6.14$ & $4.57 \pm 5.53$ \\
Gastropods & $5.11 \pm 6.51$ & $6.20 \pm 6.69$ & $4.19 \pm 5.84$ \\
Fish Remains & $8.80 \pm 7.52$ & $10.83 \pm 11.27$ & $6.40 \pm 6.19$ \\
Tintinnids & $0.54 \pm 1.81$ & $0.35 \pm 1.42$ & $0.86 \pm 1.96$ \\
Dinoflagellates & $0.53 \pm 1.69$ & $0.28 \pm 1.16$ & $1.16 \pm 2.52$ \\
Digested Matter & $1.32 \pm 3.44$ & $2.31 \pm 4.57$ & $1.21 \pm 3.98$
\end{tabular}

and that the food items were available in the sea during the entire study period.

While analysing the sex-wise preferences of diet components also not much variations $(t=1.023 ; p>0.05)$ were found to occur between male and female fishes (Fig. 3).

Analysis of prey indices of $S$. indicus for the three seasons (Table 3 ) showed that the prey diversity index $(\mathrm{H})$ did not show significant variation for the three seasons and was almost uniform throughout the seasons. The niche width index (B) for the entire study period was low ranging from 3.2 to 3.6 which indicated a constant and specialised feeding pattern with crustaceans, molluscs and small fishes forming the main food items. Prey evenness indices (e) for the three seasons indicated an almost uniform distribution of prey species throughout the study period. This also indicate the fact that the food items were available in the sea throughout the study period.

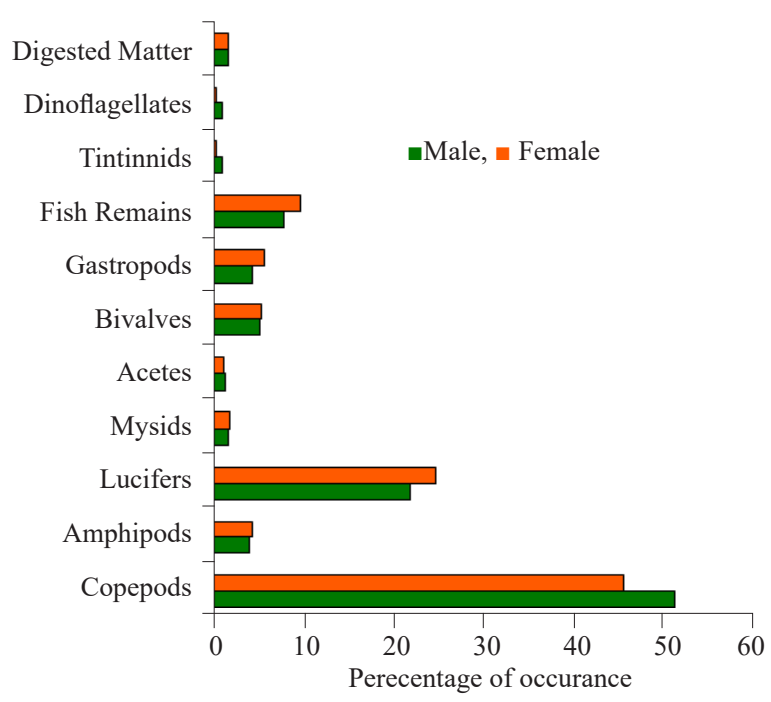

Fig. 3. Comparison of percentage occurrence of food items in male and female $S$. indicus

Table 3. Prey indices for $S$. indicus

\begin{tabular}{llll}
\hline Seasons & $\mathrm{H}$ & $\mathrm{B}$ & $\mathrm{e}$ \\
\hline Monsoon & 1.59 & 3.44 & 0.66 \\
Post-monsoon & 1.62 & 3.57 & 0.68 \\
Pre-monsoon & 1.59 & 3.28 & 0.66 \\
\hline
\end{tabular}

H-Diversity index, B-Niche width index, e-Evenness index

\section{Acknowledgements}

The authors wish to express their sincere gratitude to Dr. Rani Mary George, former Scientist-in-Charge, Vizhinjam Research Centre of ICAR-CMFRI, Vizhinjam for support and encouragement. The authors also extend their sincere gratitude to Dr. K. Murugan, Professor and Head, Department of Zoology, Bharathiar University, Coimbatore for his invaluable support and constant encouragement.

\section{References}

Babu Rao, M. 1967. Biometric studies on Anchoviella commersoni (Lacepede) (Engraulis: Pisces) from Andhra coast. J. Mar. Biol. Ass. India, 7(2): 369-375.

Bachok, Z., Mansor, M. I. and Noordin, R. M. 2004. Diet composition and food habits of demersal and pelagic marine fishes from Terengganu waters, east coast of Peninsular Malaysia. NAGA World Fish Center Quart., 27: 41-47.

Bal, D. V. and Rao, K. V. 1984. Marine fisheries. Tata McGrawHill Publishing Company, New Delhi, 470 pp.

Catalan, I. A., Folkvord, A., Palomera, I., Quilez-Badia, G., Kallianoti, F., Tselepides, A. and Kallianotis, A. 2010. Growth and feeding patterns of European anchovy (Engraulis encrasicolus) early life stages in the Aegean Sea (NE Mediterranean). Estur. Coast. Shelf Sci., 86: 299-312. 
CMFRI 2015. Annual report 2014-2015. Central Marine Fisheries Research Institute, Kochi. http://eprints.cmfri. org.in/9465.

CMFRI 2016. Annual report 2015-16. Central Marine Fisheries Research Institute, Kochi, 294 pp. http://eprints.cmfri.org. in $/ 10897$.

Cunningham, J. T. 1890. Anchovies in the English Channel. J. Mar. Biol. Ass. U. K., 1: 328-339.

Desai, V. R. 1970. Studies on the fishery biology of Tor tor (Ham.) from river Narmada I. Food and feeding habits. J. Inland Fish. Soc. India, 2: 101-112.

FAO 2006. State of world fisheries and aquaculture (SOFIA). http://www.fao.org/docrep/009/A0699e/A0699E04.htm.

Gibson, R. N. and Ezzi, I. A. 1987. Feeding relationships of a demersal fish assemblage on the west coast of Scotland. J. Fish Biol., 31: 55-69.

Gopakumar, G., Bhaskaran Achary, R. and Velayudhan, A. K. 1995. The inshore migration of Buccaneer anchovy during monsoon. Mar. Fish. Infor. Serv. T. \& E. Ser., No. 137: 16.

Gunn, J. S. and Milward, N. E. 1985. The food, feeding habits and feeding structures of the Whiting species Sillago sihama (Forsskal) and Sillago analis Whitley from Townsville, North Queensland, Australia. J. Fish Biol., 26(4): 411-427.

Hajisamae, S., Chou, L. M. and Ibrahim, S. 2003. Feeding habits and trophicorganisation of the fish community in shallow waters of an impacted tropical habitat. Est. Coast. Shelf Sci., 58(1): 89-98.

Hajisamae, S., Chou, L. M. and Ibrahim, S. 2006. Feeding ecology of two sillaginid fishes and trophic interrelations with other co-existing species in the southern part of South China Sea. Environ. Biol. Fish., 76(2-4): 167-176.

Hynes, H. B. N. 1950. The foods of freshwater stickle backs (Gasterosteus aculeatus and Pygosteus pungitius) with a review of methods used in studies of the food of fishes. J. Anim. Ecol., 19: 36-58.

Hyslop, E. J. 1980. Stomach contents analysis - a review of methods and their application. J. Fish Biol., 17: 411-429.

IMR/NORAD/FAO 1974. Progress report no. 7. Plankton -fish eggs and larvae studies. UNDP/FAO Pelagic Fishery Project (IND/69/593). NORAD/IMR, Bergen/Cochin, $54 \mathrm{pp}$

Levins, R. 1968. Evolution in changing environments: some theoretical explorations. Princeton University Press, $120 \mathrm{pp}$.

Luther, G. 1972. Whitebait fishery resources of the southwest coast of India. Proceedings of the symposium on pelagic fishery resources of theseas around India,11-13 December, 1972. Central Marine Fisheries Research Institute, Kochi.

Luther, G. 1979. Anchovy fishery of the south-west coast of India with notes on characteristics of the resources. Indian J. Fish., 26(1): 23-39.

Date of Receipt $\quad$ : $\quad 21.08 .2017$

Date of Acceptance ： 21.03 .2018
Maclean, J. L. 1971. The food and feeding of the winter whiting Sillago maculata (Quoy \& Gaimard) in Moreton Bay. Proc. Linn. Soc. NSW, 98: 87-92.

Plounevez, S. and Champalbert, G. 2000. Diet, feeding behaviour and trophic activity of the anchovy (Engraulis encrasicolus L.) in the Gulf of Lions (Mediterranean Sea). Oceanol. Acta, 23(2): 175-192.

Raab, K., Nagelkerke, L. A. J., Boeree, C., Rijnsdorp, A. D., Temming, A. and Dickey-Collas, M. 2011. Anchovy Engraulis encrasicolus diet in the North and Baltic Seas. J. Sea Res., 65: 131-140.

Rabindranath, P. 1966. Biology and seasonal distribution of the pelagic food fishes of Trivandrum coast, University of Kerala, Thiruvananthapuram, India, 140 pp.

Russell, B. C. 1983. The food and feeding habits of rocky reef fish of north-eastern New Zealand. N. Z. J. Mar. Freshwat. Res., 17: 121-145.

Schaber, M., Petereit, C. and Paulsen, M. 2010. Diet composition and feeding of European Anchovy Engraulis encrasicolus in Kiel Bight, western Baltic Sea. J. Fish Biol., 76: 1856-1862.

Shaheen, P. A., Stehlik, L. L., Meise, C. J., Stoner, A. W., Manderson, J. P. and Adams, D. L. 2001. Feeding behaviour of newly settled winter Flounder (Pseudopleuronectus americanus) on calanoid copepods. J. Exp. Mar. Biol. Ecol., 257: 37-51.

Srinivasa Rao, K. 1964. Food and feeding habits of fishes from trawl catches in the Bay of Bengal with observations on diurnal variations in the nature of feed. Indian J. Fish., 11: $277-314$

Syda Rao, G. 1988. Biology of Stolephorus devisi (Whitley) from Mangalore area, Dakshina Kannada. J. Mar. Biol. Ass. India, 30(1\&2): 28-37.

Thangavelu, R., Bose, M. and Poovannan, P. 1987. Heavy landings of Stolephorus devisi by shore seines along Madras coast. Mar. Fish. Infor. Serv. T \& E Ser., 76: 5-6.

Tudela, S. and Palomera, I. 1995. Diel feeding intensity and daily ration in the anchovy Engraulis encrasicolus in the north-west Mediterranean Sea during the spawning period. Mar. Ecol. Prog. Ser., 129: 55-61.

Venkataraman, G. 1960. Studies on the food and feeding relationships of the inshore fishes off Calicut on the Malabar coast. Indian J. Fish., 7(2): 275-306.

Vijayaraghavan, P. 1953. Food of the lndian herrings. J. Madras Univ., 22(B): 239-247.

Vijayaraghavan, P. 1957. Studies on fish eggs and larvae of Madras coast, University of Madras, Tamil Nadu, India, 79 pp. 